\title{
PARADIGMA PENDIDIKAN DEMOKRASI DAN PENDIDIKAN ISLAM DALAM MENGHADAPI TANTANGAN GLOBALISASI DI INDONESIA
}

\author{
Ali Miftakhu Rosyad \\ Universitas Wiralodra Indramayu \\ miftakhurosyad@gmail.com \\ Muhammad Anas Ma`arif \\ Anasdt16@gmail.com \\ Institut KH Abdul Chalim Mojokerto
}

\section{Naskah Diterima: 10-12-2019 Direvisi: 24-01-2019 Disetujui: 01-02-2020}

\begin{abstract}
The study aims to explore the paradigm of Islamic education, democratic education to face the globalization challenges in Indonesia. This research method was a qualitative approach with type of literature study. Paradigmatically, democratic education is the process to develop all human potentials that values of plurarity and heterogeneity as a consequence of cultural, ethnic, ethnic, and religious diversity. The emphasized main values in democratic education are equality and tolerance. Whereas in Islamic education, the values of transcendence tanght in the curriculum must be practiced in daily life in order to achieve the pious charity conference. The challenges of globalization that have penetrated into the world of education have become a driving force for inclusive and sustainable educational innovation. This study is expected to provide contributions for academician, education practical, and teacher in Indonesia as an actualization of Islamic education and democratic education to confront globalization challenges in Indonesia. The main objective of the integration of Islamic education and multicultural education is to provide student to face globalization challenge as khoirul ummah.
\end{abstract}

Keywords: democratic education, Islamic education, and globalization challenges.

\begin{abstract}
Abstrak
Penelitian ini bertujuan untuk mengeksplorasi paradigma pendidikan Islam, pendidikan demokratis untuk menghadapi tantangan globalisasi di Indonesia. Metode penelitian ini adalah pendekatan kualitatif dengan jenis studi literatur. Paradigmatically, pendidikan demokratis adalah proses untuk mengembangkan semua potensi manusia yang menghargai pluralitas dan heterogenitas sebagai konsekuensi dari keragaman budaya, etnis, etnis, dan agama. Nilai-nilai utama yang ditekankan dalam pendidikan demokratis adalah kesetaraan dan toleransi. Sedangkan dalam pendidikan Islam, nilainilai transendensi yang diajarkan dalam kurikulum harus dipraktikkan dalam kehidupan sehari-hari untuk mencapai konferensi amal saleh. Tantangan globalisasi yang telah merambah ke dunia pendidikan telah menjadi kekuatan pendorong bagi inovasi pendidikan yang inklusif dan berkelanjutan. Studi ini diharapkan dapat memberikan kontribusi bagi akademisi, praktik pendidikan, dan guru di Indonesia sebagai aktualisasi pendidikan Islam dan pendidikan demokrasi untuk menghadapi tantangan globalisasi di Indonesia. Tujuan utama dari pengintegrasian pendidikan Islam adalah untuk mewujudkan peserta didik yang siap menghadapi tantangan globalisasi sebgai khoirul ummat.
\end{abstract}

Kata kunci: pendidikan demokrasi, pendidikan Islam, dan tantangan globalisasi. 


\section{PENDAHULUAN}

Berangkat dari sebuah kata pendidikan adalah upaya untuk memanusiakan manusia. Penyelenggaraan pendidikan harus berorentasi untuk membangun dan merevitalisasi kualitas SDM (Sumber Daya Manusia) agar memiliki kompetensi sesuai kebutuhan zaman. Sesuai dengan amanat Undang-Undang tentang Sistem Pendidikan Nasional Nomer 20 tahun 2003 Pasal 3 menyatakan bahwa "pendidikan berfungsi mengembangkan kemampuan dan membentuk watak serta peradaban bangsa yang bermartabat dalam rangka mencerdaskan kehidupan bangsa". Berdasarkan definisi tersebut dapat dimaknai bahwa fungsi pendidikan tidak semata-mata mengembangkan kemampuan, namun juga dimaksudkan untuk membentuk watak, keterampilan dan peradaban suatu bangsa yang bermartabat. Bangsa yang bermartabat dicirikan dengan bangsa yang memiliki akhlak mulia dan cerdas sebagaimana yang menjadi tujuan pendidikan nasironal ${ }^{1}$.

Pendidikan sebagai isntrumen yang digunakan untuk membangun dan merevitalisasi kualitas SDM (Sumber Daya Manusia) agar memperoleh kompetensi sosial dan perkembangan individu yang optimal serta mampu memberikan relasi yang kuat antara individu, masyarakat, dan lingkungan sekitar tempat seseorang hidup ${ }^{2}$. Lebih dari itu pendidikan merupakan proses "memanusiakan manusia" yang memiliki makna kontekstual bahwa seseorang harus mampu memahami dirinya, orang lain, alam, dan lingkungan budayanya ${ }^{3}$. Atas dasar itulah pendidikan tidak bisa terlepas bahkan menjauh dari budaya yang melingkupinya sebagai konsekwensi dari tujuan pendidikan yaitu mengolah rasa, karsa, dan karya. Melihat dari tujuan yang ingin dicapai itu sistem pendidikan nasional mengalami berbagai tantangan seiring berjalanya waktu ${ }^{4}$

1 Republik Indonesia, "Undang-undang Republik Indonesia nomor 20 tahun 2003 tentang sistem pendidikan nasional," Jakarta: Pemerintab Republik Indonesia, 2003.

2 Irham Irham dan Yudril Basith, "Revitalisasi Makna Guru Dari Ajaran Tasawuf Dalam Kerangka Pembentukan Karakter," Ulul Albab Jurnal Studi Islam 19, no. 1 (25 Juni 2018): 44-68, https://doi.org/10.18860/ua.v19i1.4901; Jejen Musfah dan Desita Erviani, "School of Master Teacher (Smt) Training: Developing Teachers' Pedagogic Competence," TARBIYA: Journal of Education in Muslim Society 5, no. 2 (2018): 126-34, https://doi.org/10.15408/tjems.v5i2.10622; Yeni Yusnita dkk., "The Effect of Professional Education and Training for Teachers (PLPG) in Improving Pedagogic Competence and Teacher Performance," Tadris: Jurnal Keguruan dan Ilmu Tarbiyah 3, no. 2 (28 Desember 2018): 123-30, https://doi.org/10.24042/tadris.v3i2.2701; Brian Leavy, "Effective leadership today - character not just competence," Strategy \& Leadership 44, no. 1 (11 Januari 2016): 20-29, https://doi.org/10.1108/SL-11-2015-0081.

${ }^{3}$ Nicolaus Driyarkara, Driyarkara tentang pendidikan, vol. 1 (Yayasan Kanisius, 1980).

4 Fitri Oviyanti, “Tantangan Pengembangan Pendidikan Keguruan di Era Global," Nadwa 7, no. 2 (2016): 267-82; Andika Aprilianto dan Muhammad Arif, "Pendidikan Islam Dan Tantangan Multikultural: Tinjauan Filosofis," Nazhruna: Jurnal Pendidikan Islam 2, no. 2 (11 Agustus 2019): 279-89, https://doi.org/10.31538/nzh.v2i2.339; Juli Amaliya Nasucha, "Pendidikan Islam Dan Tantangan Globalisasi," JOIES: Journal of Islamic Education Studies 1, no. 1 (7 September 2016): 205-18. 
Berdasarkan fakta yang terjadi, memasuki abad ke-21, berbagai isu mengenai revitalisasi pada sekotor pendidikan kembali fenomenal yang terjadi pada semua jenjang, jalur, dan jenis pendidikan ${ }^{5}$. Oleh karena itu, gagasan-gagasan tentang reformasi dan demokratisasi pendidikan di Indonesia sangat relevan, terutama dalam konteks meningkatkan kualitas SDM yang handal yang harus dimulai dengan perbaikan pendidikan semua jenis, jalur, dan jenjang pendidikan dengan perbaikan yang komprehensif ${ }^{6}$. Perubahan yang komprehensif dapat dilakukan pada tataran makro dengan cara pengembangn regulasi, sistem, dan berbagi standarisasi pendidikan? ${ }^{7}$ Sedangkan perbaikan komprehensif pada tataran mikro yakni di tingkat sekolah dilakukan dengan berbagi perbaikan dalam aspek perencanaan, proses pembelajaran, dukungan alat dan sarana, dan perbaikan manajemen untuk mencapai hasil pendidikan yang maksimal ${ }^{8}$.

Berdasarkan hasil penelitian yang telah dilakukan oleh Erlan Muliadi tentang urgensi peembelajaran Pendidikan Agama Islam berbasis multikultural di Sekolah menjelaskan bahwa Pelajaran Pendidikan Agama Islam yang bernuansa teologis di sekolah sebatas diajarkan berbagai materi yang bertujuan untuk meningkatkan nilai spriritualitas (keimanan, ketaqwaan, dan mencapai surga) tanpa dibarengi dengan kesadaran dialogis untuk menghadapi perbedaan pada suku, budaya, agama, dan bahasa (kesadaran multikultural). Kondisi yang demikian apabilan tidak segeran dicarikan jalan keluarnya akan menjadikan Pendidikan Agama Islam bersifat ekslusif dan intoleran. Padahal di era multikulturalisme saat ini, Pendidikan Agama Islam perlu melakukan reorentasi perubahan paradigmatik dari segi tujuan, materi, metode, dan mendia yang digunakanya serga perlu dicarikan jalan keluar bagaimana membangun pemahaman keberagamaan peserta didik yang lebih inklusif-pluralis, multikultural, humanis,

5 Achmad Asrori, "Contemporary Religious Education Model on the Challenge of Indonesian Multiculturalism," JOURNAL OF INDONESLAN ISLAM 10, no. 2 (1 Desember 2016): 261-84, https://doi.org/10.15642/JIIS.2016.10.2.261-284; Muhammad Amin Abdullah, "Islamic Studies in Higher Education in Indonesia: Challenges, Impact and Prospects for the World Community," Al-Jami'ab: Journal of Islamic Studies 55, no. 2 (15 Desember 2017): 391-426, https://doi.org/10.14421/ajis.2017.552.391-426; Mohammad Hamid Mohammad al-Aharish, "Indonesian Islam and Social Challenges Between Moral Cultivation and Intellectual Movement," Journal of Indonesian Islam 11, no. 2 (6 Desember 2017): 551-568-568, https://doi.org/10.15642/JIIS.2017.11.2.551-568.

${ }^{6}$ Duna Izfanna dan Nik Ahmad Hisyam, “A comprehensive approach in developing akhlaq: A case study on the implementation of character education at Pondok Pesantren Darunnajah," Multicultural Education \& Technology Journal 6, no. 2 (8 Juni 2012): 77-86, https://doi.org/10.1108/17504971211236254; Kata Kunci, “The Urgency of Holistic and Comprehensive Character Education in Indonesia," Jurnal Pendidikan Karakter, $2013,8$.

7 Dede Rosyada, Paradigma pendidikan demokratis: sebuah model pelibatan masyarakat dalam penyelenggaraan pendidikan (Prenada Media, 2004).

8 Ali Miftakhu Rosyad, “The IMPLEMENTASI NILAI-NILAI MULTIKULTURALISME MELALUI PEMBELAJARAN PENDIDIKAN AGAMA ISLAM (THE IMPLEMENTATION OF MULTICULTURALISM VALUES THROUGH LEARNING OF ISLAMIC RELIGION EDUCATION)," Risâlah, Jurnal Pendidikan dan Studi Islam 5, no. 1 (2019): 1-18. 
dialogis-persuasif, kontekstual, substantif dan aktif sosial ${ }^{9}$. Dalam penelitian tersebut hanya menjelaskan mengenai kuriklum dan peran guru PAI dalam pembelajaran disekolah yang bersifat filosofis. Adapun dalam penelitian ini akan mencoba mengurai bagaimana paradigma pendidikan demokrasi, pendidikan Islam dalam menghadapi tantangan global.

Hasil penelitian lain yang telah dilakukan oleh Toto Suharto mengemukakan bahwa dalam pengintegrasian pendidikan Islam dan pendidikan demokrasi terhadap dua paradigm berpikir dalam merespon hal tersebut yaitu kelompok Islam mainstream melakukannya dengan paradigma "Indonesianisasi Islam", sementara kelompok Islam transnasional melakukannya dengan paradigm "Islamisasi Indonesia"10. Kedua paradigma pengislaman ini kini saling berebut Islam Indonesia melalui salurannya masing-masing, utamanya melalui lembaga pendidikan Islam sebagai langkah yang paling strategis. Namun dalam hal tersebut belum dijelaskan bagaimana pemecahan yang harus dilakukan dalam perspektif dunia pendidikan. Penelitian ini akan mencoba mengkaji interkoneksi pendidikan islam dan demokrasi untuk mewujudkan khoirul ummah.

Sebagaimana kita saksikan bersama bahwa wajah monokulturalisme sering muncul sehingga melahirkan kekacauan social. Apabila diimplementasikan secara maksimal pendidikan multikultural dapat digunakan baik pada tingkat deskriftif dan normative, yang menggambarkan isu-isu dan maslah-masalah pendidikan yang berkaitan dengan masyarakat multicultural $^{11}$. Lebih jauh ia juga mencakup pengertian tentang pertimbangan terhadap kebijakan-kebijakan dan strategi-strategi pendidikan dalam masyarakat multicultural yang jelas mencakup subjek-subjek seperti: toleransi, tema-tema tentang perbedaan ethno-kultural dan agama: bahaya diskriminasi, penyelesaian konflik, demokratis dan pluralitas, kemanusiaan universal dan lain sebagainya. Dalam pelaksanaanya hal tersebut membutuhkan kesadaran bersama.

Berdasarkan hasil penelitian dan pemaparan tersebut perlu sekiranya dilakukan penelitian dan kajian akademis mengenai paradigma pendidikan demokrasi, pendidikan islam dalam menghadapi tantangan global. Secara mendasar Islam bukan sekedar agam ritual dan ibada semata, akan tetapi Islam adalah way of life yang memberikan pedoman kepada setiap orang dalam berbagai aspek kehidupan. Melihat semakin banyaknya kasus paham radikalisme, terorisme, dan fundamentalisme yang menyebar semakin luas dengan berbagai cara, saatnya

\footnotetext{
9 Erlan Muliadi, "Urgensi Pembelajaran Pendidikan Agama Islam Berbasis Multikultural di Sekolah," Jurnal Pendidikan Islam 1, no. 1 (2011): 55-68.

10 Toto Suharto, "Indonesianisasi Islam: Penguatan Islam Moderat dalam Lembaga Pendidikan Islam di Indonesia," Al-Tabrir: Jurnal Pemikiran Islam 17, no. 1 (2017): 155-78.

11 Zulkarnain Dali, "Pendidikan Islam Multikultural," Nuansa 10, no. 1 (2017).
} 
kini dunia pendidikan khususnya sekolah untuk ikut berpartisipasi aktif dalam menenamkan doktrin pentingnya moderasi beragama. Missi utama Pendidikan Agama Islam adalah sebagai mesin penggerak perubahan globalisasi dan sistem pendidikan agar mampu membawa kemaslahatan bagi kehidupan manusia.

Sebagaimana fakta yang telah terjadi pada akhir dekade kali ini memang wajah monokulturalisme dalam dunia pendidikan kini masi terasa apabila kita perhatikan dari berbagai dimensi pendidikan ${ }^{12}$. Berawal dari Kurikulum pembelajaran, muatan materi, sampai pada pendekatan dan metode pengajaran yang digunakan dalam proses pembelajaran masih cenderung konfensiona dan konservatif. Lebih ironisnya lagi, hingga dipenghujuang abad ke20 sistem penyelenggaraan pendidikan di Indonesia masih didominasi oleh pendekatan topdown (model instruksional terpusat) dengan kekuassaan birokrasi yang ketat, bahkan otoriter. Dengan kondisi demikian tuntutan untuk demokratisasi pendidikan akan semakin mencuak.

Eksistensi Pendidikan Agama Islam dan Budi Pekerti pada masa reformasi ini harus dimaknai sebagai jalan keluar yang mampu memberikan angin segar dan mampu mengantar bangsa Indonesia menciptakan suasana suasana pendidikan yang demokratis ${ }^{13}$, good governance, negara hukum, dan civil society yang relevan dengan tuntutan global. Secara simple dengan dilaksanakanya demokratisasi pendidikan dan pembaharuan sistem pembelajaran pendidikan Islam akan menciptakan profil warga negara yang good citizen and smart citizen sesuai dengan missi agama Islam dan konstitusi negara. ${ }^{14}$ Tentunya ekspektasi ini harus disertai dengan tindakan nyata bangsa ini, khususnya kaalangan Perguruan Tinggi, untuk mengapresiasi dan mengimplementasikan Pendidikan Agama Islam dalam dunia pendidikan.

Berdasarkan berbagai konsep dan hasil penelitian tersebut dipadang urgen sekiranya ada penelitian dan kajian akademik mengenai analisis eksistensi pendidikan demokrasi dan pendidikan Islam dalam menghadapi tantangan global. Kedua paradigma itu (pendidikan demokrasi dan pendidikan Islam) memiliki tujuan yang sama yaitu untuk mencerdaskan kehidupan bangsa melalui suatu jalur, jenjang, dan jenis pendidikan.

12 Subandi Subandi dkk., "Implementation of Multicultural and Moderate Islamic Education at the Elementary Schools in Shaping the Nationalism," Tadris: Jurnal Keguruan Dan Ilmu Tarbiyah 4, no. 2 (27 Desember 2019): 247-55, https://doi.org/10.24042/tadris.v4i2.5003; Ammar Zainuddin dan Juli Amaliya Nasucha, "The Internalization of Sunan Drajat Social Concept in Multicultural Education Implementation," Al-Tadzkiyyah: Jurnal Pendidikan Islam 9, no. 1 (30 Mei 2018): 167-80, https://doi.org/10.24042/atjpi.v9i1.2958.

13 Mundzier Suparta, "Pendidikan Transformatif Menuju Masyarakat Demokratis," ISLAMICA: Jurnal Studi Keislaman 7, no. 2 (23 Januari 2014): 406-25, https://doi.org/10.15642/islamica.2013.7.2.406-425.

14 Muhammad Kosim dkk., "Strengthening Students' Character through Tahfidz Quran in Islamic Education Curriculum," Jurnal Pendidikan Islam 8, no. 1 (4 September 2019): 69-94, https://doi.org/10.14421/jpi.2019.81.69-94. 


\section{METODE PENELITIAN}

Penelitian ini menggunakan pendekatan kualitif dengan jenis penelitian pustaka (library research). Sumber data penelitian ini diperoleh dari buku-buku dan jurnal-jurnal ilmiah yang berkaitan dengan pendidikan demokrasi, pendidikan islam, tantangan pendidikan global, dan inovasi pendidikan. Pendekatan kualitatif dipilih mengingat tujuan dari penelitiam ini adalah untuk memperoleh gambaran bagaimana keterkaitan pendidikan demokrasi dan pendidikan Islam dalam menghadapi tantangan blobalisasi.

\section{PEMBAHASAN}

\section{Paradigma Pendidikan Demokrasi}

Secara mendasar dan normatif, paradigma adalah sebagai seperangkat kepercayaan atau keyakinan dasar yang menentukan seseorang dalam bertindak pada kehidupan sehari-hari. Selain itu ada definisi lain yang mengatakan bahwa paradigma adalah suatu citra atau gambaran yang sangat esensial dari suatu pokok pembahasan suatu ilmu. Paradigma memberikan suatu pedoman yang digariw bawahi mengenai apa yang harus dipelajari, pernyataan-pernyataan apa yang seharusnya dikemukakan, dan kaidah-kaidah apa yang seharusnya diikuti dalam menafsirkan jawaban yang diperolehnya. Dengan demikian, maka paradigma adalah ibarat sebuah menara tempat orang mengamati dunia sekeliling sehingga memperoleh wawasan yang diharapkan ${ }^{15}$.

Pendapat lain diperkuat oleh Thomas Kuhn, paradigma sebagai sseperangkat keyakikan-keyakinan mendasar yang dijadikan sebagai navigasi yang memandu tindakantindakan kita, baik tindakan keseharian maupun dalam investigasi ilmiah. Selanjutnya ia mengartikannya sebagai (a) a set of assumption, and (b) the beliefs concerning: yaitu sebuah asumsi yang dianggap benar secara (given). Supaya bias sampai pada sumsi tersebut maka, diperlukan adanya perlakuan empirik (melalui pengamatan) yang yang dapat menyimpulkan hal tersebut; accepted assume to be true ${ }^{16}$. Dengan demikian paradigma dapat dikatakan sebagaia mental window, tempat yang terdapat "frame" yang tidak membutuhkan pembuktian akan pembenaranya karena masyarakat pendukung paradigma telah memiliki kepercayaan demikian.

Definisi demokrasi secara etimologi berasal dari bahasa Yunani yaitu demos (rakyat) dan kratos (pemerintahan). Demokrasi adalah sistem pemerintahan dari rakyat, oleh rakyat,

\footnotetext{
15 Mohammad Muslih, FILSAFAT ILMU; Kajian atas Asumsi Dasar, Paradigma, dan Kerangka Teori Ilmu Pengetahuan (LESFI, 2016). 1989.

16 Roy Bhaskar, "The Possibility of Naturalism,(2nd edn) Hemel Hempstead: Harvester Wheatsheaf,"
} 
dan untuk rakyat. Dengan kata lain suatu sistem pemerintahan di mana rakyat memegang kekuasaan tertinggi dalam melakukan kontrol sosial. Dewasa ini, system pererintahan demokrasi telah diterima oleh hamper seluruh Negara di dunia. memiliki tiga unsur utama, yaitu: adanya kemauan politik sebuah Negara (state), adanya kemauan yang kuat dari politik masyarakat (political society), dan adanya civil society yang kuat dan mandiri. Ketiga unsur ini diproses dalam sebuah negara dengan tujuan untuk menjamin adanya kekuasaan mayoritas, suara rakyat dan pemilihan umum yang dilangsungkan dengan prisip langsung, umum, bebas, dan rahasia. ${ }^{17}$.

Setelah itu untuk mewujudkan tatanan kehidupan yang demokratis dalam berbagai aspek kehidupan perlu diupayakan suatu proses demokratisasi. Demokratisasi adalah suatu proses berkelanjutan untuk menuju demokrasi. Dalam konteks pendidikan merupakan sarana dan kesempatan palin strategis untuk mewujudkan iklim demokratisasi. Pendidikan demokrasi dapat dipahami sebagai suatu proses sosialisasi, internalisasi, dan aktualisasi konsep, dan nilainilai demokrasi melalui proses pembelajaran berlangsung. Dalam kaitan ini, upaya untuk mewujudkan system pendidikan yang demokratis menjadi keharusan yang perlu disikapi secara posifit oleh seluruh praktisi pendidikan ${ }^{18}$. Sistem demokratisasi pendidikan akan berjalan dengan baik sesuai koridor apabila semua warga negara memahami, menyadari, dan mendukung proses itu.

Selain itu pendapat lain yang dikemukakan oleh Zamroni, Paradigma pendidikan demokrasi secara eksplisit yang menjadi concern dari proses penyelenggaraan pendidikan di Negara hukum Republik Indonesia yang tertuang pada UU No. 20 tahun 2003 Pasal 4 yang menjelaskan pendidikan diselenggarakan secara demokratis, tidak diskriminatif, dengan menjunjung tinggi HAM, nilai keagamaan, nilai kultural, dan kemajemukan bangsa ${ }^{19}$. Dalam konteks pendidikan di Indonesia, kajian mengenai pendidikan demokrasi dan pendidikan multicultural semakin memperoleh momentum pasca runtuhnya rezim orde baru yang otoriter militeristik karena hembusa angin segar reformasi. Era reformasi bukan hanya membawa berkah bagi bangsa Indonesia tetapi disisi lain member peluang meningkatnya primodialisme. Untuk itu, perlu dilaksanakan system pendidikan demokrasi yang ideal untuk menangkal sifat promodial, individual, dan intoleran. (2005).

17 Toto Suharto, "Konsep dasar pendidikan berbasis masyarakat," Jurnal Cakrawala Pendidikan, no. 3

18 Zamroni, Pendidikan untuk demokrasi: tantangan menuju civil society (Bigraf Pub., 2001).

${ }^{19}$ Zamroni. (2013). Pendidikan demokrasi padamasyarakat multikultural. Yogyakarta:Gavin KalamUtama. 
Analisis rasional perlu adanya reformasi pendidikan sebagaimana dikatakan oleh Dede Rosyada $^{20}$ adalah: a) perubahan pola pikir masyarakat akibat demokratisasi yang terus menjangkau pada seluruh aspek kehidupan, b) perubahan dunia yang sangat cepat, dan para siswa harus dipersiapkan untuk menghadapi perubahan tersebut, c) kemajuan teknologi dalam semua sektor industri dan layanan jasa akan kian menggeser posisi manusia, d) penurunan standar hidup yang terjadi dimana tenaga manusia akan digantikan oleh tenaga mesin, e) pemahaman doktrin agama semakin inklusif dan terbuka, dan $\mathrm{f}$ ) peran media masa yang terus menguat dan terus mensosialisasikan perubahan sosial.

Kalau kita melihat dari kondisi sosio kultural negara ini pada hakikatnya adalah sebuah kewajaran jika sebuah organisasi sosial maupun politik ada kepentingan-kepentingan yang harus diperjuangkan. Dan tidak satupun organisasi sosial atau politik yang bertujuan untuk memperjuangkan nilai-nilai buruk.

Kasus negatif yang sering terjadi dalam konteks kehidupan berbangsa dan bernegara, jelas patut disayangkan maraknya konflik kekerasan yang bisa mengoyak persatuan dan kesatuan warga serta keutuhan NKRI. Kenyataan ini sudah saatnya menginspirasi kita, kalangan terdidik, untuk merefleksikan kearifan tersebut dan mengartikulasikannya dalam kehidupan bermasyarakat, berbangsa, dan bernegara sehingga kehadiran dan kiprah kita layak dinilai kontributif dalam merajut keharmonian, kerukunan, dan integrasi nasional. Ibarat sebuah pelangi, kemajemukan warga-masyarakat dan warga-negarajustru mampu melahirkan mozaik keserasian dan keterpaduan warna-warni karena disikapi dan dikelola dengan penuh kearifan ${ }^{21}$

Salah satu tantangan serius yang dihadapi oleh sistem pendidikan demokrasi adalah globaliasasi dalam berbagai aspek kehidupan yang bersifat multidimensi. Globalisasi yang mempengaruhi gaya hidup sekurang-kurangnya ditandai oleh kuatnya pengaruh institusi dan lembaga sosial pada tingkat internasional ketika bersaing dengan negara-negara maju yang ikut mengatur perpolitkan, perekonomian, sosial budaya, dan pertahanan global. Isu-isu global seperti demokrasi, hak asasi manusia dan lingkungan hidup turut pula mempengaruhi kondisi nasional bangsa Indonesia. salah satu dampak globalisasi yang terjadi dalam aspek pesatnya perkembangan ilmu pengetahuan dan teknologi, informasi, komunikasi adalah membuat dunia semakin sempit dan transparan yang seolah-olah menjadi satu kampung tanpa batas Negara.

\footnotetext{
${ }^{20}$ Rosyada, Paradigma pendidikan demokratis: sebuah model pelibatan masyarakat dalam penyelenggaraan pendidikan. ${ }_{21}$ Mahmud Arif, "Pendidikan Agama Islam Inklusifmultikultural," Jurnal Pendidikan Islam 1, no. 1 (2011):
} $1-18$. 
Menyadari akan tantangan perubahan multidimensi, baik lokal, nasional, maupun global semakin berat, Pendidikan Agama Islam sebagai mata pelajaran wajib diharapkan mampu menumbuhkan sikap spiritua dan emosional yang cerdas, tanggung jawab, dan memiliki kompetensi amal sholeh yang dapat diaplikasikan dalam kehidupan sehari-hari. Singkatnya adalah materi yang diajarkan dalam kurikulum pendidikan dapat menjawab semua tantangan kehidupan masyarakat.

Sejak jatuhnya rezim orde baru yang ditandai dengan era reformasi, demokrasi merupakan kosa kata hangat yang sering dilontarkan dalam kehidupan berbangsa dan bernegara yang majemuk ini. Gelombang demokrasi menjadi kosa kata yang ampuh untuk menuntut adanya kebebasan dan keseteraan dalam kehidupan berbangsa dan bernegara. Oleh sebag itu, pendidikan demokrasi dapat dimanifestasikan sebagai wujud kesadaran tentang keanekaragaman budaya, hak-hak asasi manusia, dan pengurangan atau penghapusan jenis prasangka atau prejudice untuk suatu kehidupan masyarakat yang adil dan maju ${ }^{22}$.

Pendidikan demokrasi memiliki mata rantai keterkaitan dengan pendidikan multikultural. Adapun konsep dari pendidikan multikultural yang ditawarkan Zamroni adalah sebagai berikut

a. Pendidikan multikultural adalah jantung untuk menciptakan kesetaraan pendidikan bagi seluruh warga masyarakat.

b. Pendidikan multikultural bukan sekedar perubahan kurikulum atau perubahan metode pembelajaran.

c. Pendidikan multikultural mentransformasi kesadaran yang memberikan arah kemana transformasi praktik pendidikan harusmenuju.

d. Pengalaman menunjukan bahwa upaya mempersempit kesenjangan pendidikan salah arah yang justru menciptakan ketimpangan semakin membesar.

e. Pendidikan multikultural bertujuan untuk berbuat sesuatu, yaitu membangun jembatan antara kurikulum dan karakter guru, pedagogi, iklim kelas, dan kultur sekolah guna membangun visi sekolah yang menjunjung kesetaraan ${ }^{23}$.

Hal tersebut senada dengan yang telah diungkapkan oleh Anas Ma'arif bahwa pentingnya internalisasi nilai multikultural di berbagai lembaga pendidikan apalagi di integrasikan dalam pembelajaran agama. Sangat penting dilakukan mengingat Indonesia terdiri dari berbagai jenis

\footnotetext{
22 Akhmad Hidayatullah Al Arifin, "Implementasi Pendidikan Multikulutral dalam Praksis Pendidikan di Indonesia," Jurnal Pembangunan Pendidikan: Fondasi dan Aplikasi 1, no. 1 (2012).

${ }^{23}$ Rohmat Rohmat, Zamroni Zamroni, dan Achmad Dardiri, "Perspektif Multikultural pada Pendidikan Agama Islam di Madrasah Aliyah,” Jurnal Pembangunan Pendidikan: Fondasi dan Aplikasi 3, no. 1 (2015): 31-43.
} 
suku, budaya dan agama. Strategi untuk menginternalisasikan juga bisa diintegrasikan dalam pembelajaran pada materi Pendidikan Islam, yang mana guru harus bisa menjadikan peserta didik toleransi dan saling menghargai. Implementasi pendidikan multikultural terdiri dari dua aspek yaitu secara kualitatif dan kuantitatif. Secara kualitatif adalah pada impelemntasi konsep yang secara sistematis, sedangkan secara kuantitatif yaitu pendidikan multikultural belum terisolasi dengan baik terutama di lembaga tinggi (kampus) ${ }^{24}$.

Melalui implementasi pendidikan demokrasi secara optimal kita dapat mensosialisasikan kepada seluruh siswa tanpa memandang status sosioekonomi; gender; orientasi seksual; atau latar belakang etnis, ras atau budaya kesempatan yang setara untuk belajar di sekolah. Pendidikan demokrasi juga didasarkan pada kenyataan bahwa siswa tidak belajar dalam kekosongan, budaya mereka memengaruhi mereka untuk belajar dengan cara tertentu. Untuk mewujudkan harapan-harapan di atas, langkah konkrit yang harus dilakukan adalah mengemas dan mengisi kurikulum Kurikulum 2013.

\section{Paradigma Pendidikan Islam}

Secara terminologis, paradigma merupakan a total view of a problem; a total outlook, not just a problem in isolation. Paradigma adalah cara pandang atau cara berpikir tentang sesuatu. Senada dengan Priatna yang menyimpulkan paradigma dapat juga diilustrasikan sebagai kacamata. Paradigma dalah bingkai (frame) sebuah kacamata, sementara sikap adalah lensa kacamata tersebut. Kita meliht dunia di sekitar kita menggunakan keduanya. Dengan demikian, paradigma bukanlah sikap. Atau sebaliknya, sikap adalah lensa kacamata. Sikap ini terkurung dalam sebuah bingkai, yaitu paradigma. Berdasarkan paradigma itu yang membingkai sikap itulah kita bertindak dan berperilaku. Secara sederhana, paradigma pendidikan dapat dipahami sebagai cara pandang dan totalitas premis mengenai pendidikan ${ }^{25}$.

PAI adalah sebuah mata pelajaran wajib yang diselenggarakan di sekolah/madrasah. Dalam praktiknya ada beberapa perbedaan yang sangat menonjol terutama pada alokasi jam yang diberikan disekolah dan madrasah. Jika disekolah pengalokasian jam PAI lebih sedikit hanya 3 SKS dalam Kurikulum 2013 dibandingkan di madrasah oleh sebab itu beberapa lembaga seperti madrasah di tuntut lebih optimal pembelajaranya dari pada di sekolah ${ }^{26}$.

${ }^{24}$ Muhammad Anas Maarif, "Internalisasi Nilai Multikulutural Dalam Mengembangkan Sikap Toleransi (Studi Di Di Pesantren Mahasiswa Universitas Islam Malang)," Naz̧hruna: Jurnal Pendidikan Islam 2, no. 1 (2019): 164-89.

25 Rudi Ahmad Suryadi, "Visi dan Paradigma Pendidikan Agama Islam (PAI): Kualitas, Integratif, dan Kompetitif," EDUKASI: Jurnal Pendidikan Islam 4, no. 2 (2016): 253-76.

26 Muhammad Anas Maarif, "Optimalisasi Pembelajaran Pendidikan Islam Di Sekolah/Madrasah Upaya Dan Faktor Penghambat Pembelajaran Pendidikan Islam,” FALASIFA: Jurnal Studi Keislaman 8, no. 2 (2017): 273-90. 
Pembelajaran PAI diharuskan mampu mewujudkan peserta didik yang dapat mengaplikasikan materi-materi yang disampaikan oleh pendidik kedalam sehari-hari. Dari sini peran pendidik sengatlah diperlukan untuk membantu peserta didik mengembangkan kompetensinya.

Secara praktis, pendidikan Islam adalah aktivitas bimbingan yang disengaja untuk mencapai kepribadian muslim, baik yang berkenaan dengan dimensi jasmani, ruhani, akal maupun moral. Pendidikan Islam adalah proses bimbingan secara sadar seorang pendidik sehingga aspek jasmani, ruhani dan akal anak didik tumbuh dan berkembang menuju terbentuknya pribadi, keluarga dan masyarakat yang Islami ${ }^{27}$. Pendapat lain yang senada mengemukakan bahwa pendidik dalam rangka mempersiapkan peserta didik untuk meyakini, memahami, dan mengamalkan ajaran Islam melalui kegiatan bimbingan, pengajaran atau pelatihan yang telah ditentukan untuk mencapai tujuan yang telah ditetapkan ${ }^{28}$. Oleh karena itu, peran guru PAI sangat diperlukan untuk menciptakan iklim pembelajaran yang kondusif.

Berdasarkan tujuan intstruksional tersebut Pendidikan Agama Islam diharapkan mampu menghasilkan kompetensi lulusan yang selalu berupaya menyempurnakan iman, takwa, dan berakhlak mulia, akhlak mulia mencakup etika, budi pekerti, atau moral sebagai perwujudan dari pendidikan ${ }^{29}$. Manusia seperti itu diharapkan tangguh dalam menghadapi tantangan, hambatan, dan perubahan yang muncul dalam pergaulan masyarakat baik dalam lingkup lokal, nasional, regional maupun global. Pendidikan agama merupakan salah satu materi yang bertujuan meningkatkan akhlak mulia serta nilai-nilai spiritual dalam diri anak.

Hal tersebut menunjukkan bahwa pendidikan agama Islam mempunyai peranan yang penting dalam implementasi pendidikan karakter disekolah. Pendidikan agama, khususnya pendidikan agama Islam (PAI) mempunyai posisi yang penting dalam sistem pendidikan nasional ${ }^{30}$. Pendidikan agama menjadi materi yang wajib diajarkan pada setiap sekolah. Pendidikan agama Islam pada prinsipnya memberikan pembelajaran yang menanamkan nilainilai spiritualitas pada peserta didik agar menjadi manusia yang berakhlak, beretika serta berbudaya sebagai bagian dari tujuan pendidikan nasional. Sedangkan Pelaksanaan pembelajaran pendidikan agama disekolah dapat diinternalisasikan dalam kegiatan intra

27 Tedi Priyatna, "Inovasi pembelajaran PAI di sekolah pada era disruptive innovation," Jurnal Tatsqif 16, no. 1 (2018): 40.

28 A Pengertian Pendidikan Agama Islam PAI, "Pendidikan Agama Islam,” 1998.

29 Badan Standar Nasional Pendidikan, "Kurikulum Tingkat Satuan Pendidikan," Jakarta: Departemen Pendidikan Nasional, 2006. 38.

${ }^{30}$ Nur Ainiyah, "Pembentukan Karakter Melalui Pendidikan Agama Islam,” Al-Ulum 13, no. 1 (2013): 25- 
maupun ekstra sekolah dan lebih mengutamakan pengaplikasian ajaran agama dalam kehidupan sehari-hari.

Secara Islami, proses pemberian bimbingan yang diberikan kepada siswa harus bernuansa pada ajaran Alquran dan Sunnah. Pendidikan Islam memiliki tanggung jawab dan PR begitu besar dalam menghadapi tantangan globalisasi yang berjalan begitu cepat agar tidak kehilangan ruh dan substansinya. Adapun fungsi pendidik adalah (1). Sebagai contoh (uswatun hasanan untuk peserta didik (2). Sebagai pendidik (3). Sebagai pengajar dan pembimbing (4). Sebagai pelajar maupun administrator pendidikan ${ }^{31}$.

Salah satu keunikan masyarakat Indonesia adalah masyarakat yang majemuk dan multikultur, bahkan multikulturalisme merupakan kekayaan yang dimiliki oleh bangsa ini. Kemajemukan dan keragaman budaya adalah sebuah fenomena yang tidak mungkin dihindari. Kita hidup di dalam keragaman budaya dan merupakan bagian dari proses kemajemukan, aktif maupun pasif. Ia telah menjiwai dalam setiap seluruh ruang kehidupan kita, tak terkecuali juga dalam hal kepercayaan. Jika dilihat dari sisi agama, multikulturalisme menjadi faham-faham keagamaan yang dianut, oleh karena itu Tuhan juga tidak dilihat sebagai bencana, tetapi justru diberi ruang untuk saling bekerjasama agar tercipta suatu sinergitas ${ }^{32}$.

Secara esensial, tujuan pendidikan Islam bukan sebatas mengisi pikiran siswa dengan ilmu pengetahuan dan materi pelajaran semata, akan tetapi membersihkan jiwanya yang harus diisi dengan akhlak dan nilai-nilai yang baik dan dikondisikan supaya biasa menjalani hidup dengan baik. Dari tujuan pendidikan Islam tersebut, dapat disimpulkan bahwa siswa diharapkan dapat menjadi manusia yang berakhlak mulia dan dapat menghargai keragaman budaya di sekitarnya. Hal tersebut senada dengan prinsip yang ada dalam pendidikan demokrasi. Dalam literatur pendidikan Islam, Islam sangat menaruh perhatian (concern) terhadap segala budaya dan tradisi ('urf) yang berlaku di kalangan umat manusia dalam setiap waktu dan kondisi, baik yang bersifat umum atau hanya berlaku dalam satu komonitas ${ }^{33}$. Hal ini dapat dibuktikan dengan banyaknya ketetapan-ketetapan dalam Islam yang berdasarkan 'urf yang berlaku dalam kehidupan masyarakat.

Pendapat tersebut dipekuat oleh pendapat yang senada bahwa tujuan pendidikan demokrasi yang sesuai dengan tujuan Islam yang berbunyi: “ Tujuan umum syari’ah Islam

${ }^{31}$ Muhammad Anas Maarif, "Pendidikan Islam Dan Tantangan Modernitas (Input, Proses Dan Output Pendidikan Di Madrasah)," Nidhomul Haq: Jurnal Manajemen Pendidikan Islam 1, no. 2 (2016): 47-58.

32 Mudjahirin Thohir, "Nasionalisme Indonesia: Membingkai Pluralitas dalam Kedamaian," dalam Zudi Setiawan, Nasionalisme NU, Semarang: Aneka Ilmu, 2007.

33 Rustam Ibrahim, "Pendidikan Multikultural: Pengertian, Prinsip, dan Relevansinya dengan Tujuan Pendidikan Islam,” Addin 7, no. 1 (2015). 
adalah mewujudkan kepentingan umum melalui perlindungan dan jaminan kebutuhankebutuhan dasar (al-daruriyyah) serta pemenuhan kepentingan (al-hajizyat) dan penghiasan (tabsiniyyah) mereka." Dari konsep inilah kemudian tercipta sebuah konsep al-daruriyyah alkhamsah (lima dasar kebutuhan manusia), yang meliputi jiwa (al-nafs), akal (al-aqb), kehormatan (al-irdh), harta benda (al-mal), dan agama (al-din $)^{34}$. Maksudnya adalah pendidikan Islam memiliki prinsip sustainable maintenance yakni pemeliharaan berkelanjutan terhadap berbagai kebutuhan dan kepentingan manusia sesuai dengan kebutuhan zamanya.

Dalam Islam, sistem demokrasi sendiri telah dibenarkan dan dipraktekkan oleh beberapa negara Muslim. Penerimaan ini disebabkan apa yang dianggap prinsip-prinsip demokrasi sesungguhnya juga terkandung dalam ajaran Islam seperti keadilan ('adl), persamaan (musawah), dan musyawarah (syura). Dengan demikian, konsep demokrasi dalam pendidikan Islam merupakan suatu tawaran yang dapat diterima untuk mewujudkan tujuan membentuk manusia yang taat pada ajaran Islam itu sendiri. Agar umat Islam dapat berkompetisi dalam peradaban global, maka konsep tersebut perlu diimplementasikan dalam sistem pendidikan Islam saat ini ${ }^{35}$.

Berdasarkan berbagai konsep diatas dapat disimpulkan bahwa paradigma pendidikan islam adalah aktualisasi nilai-nilai ajaran islam yang dilakukan secara sistematis dan terencana untuk membentuk insan robbani dan peserta didik memiliki kompetensi amal sholeh yang dapat diterapkan dalam kehidupan sehari-hari di masyarakat.

\section{Tantangan Globalisasi}

Secara sederhana globalisasi merupakan sebuah mesin penggerak perubahan sosial yang menghadirkan 2 sisi yang berbeda tetapi saling mempunyai keterkaitan,sebagaimana 2 sisi mata uang yang saling berhubungan. Di satu sisi, globalisasi telah menghadirkan pemikiran yang mengarahkan dunia menjadi semakin seragam dan terstandar melalui penyesuaian kebudayaan, teknologi, dan perdagangan, yang berasal dari dunia Barat. Tetapi di sisi lain globalisasi meningkatkan sensitifitas terhadap perbedaan budaya antar bangsa. Berdasarkan pendekaan interkoneksi globalisasi berkaitan erat dengan modernisasi, yang dalam perkembangannya telah melahirkan efek-efek positif, misalnya rasionalisasi, standarisasi dan kontrol, namun demikian modernisasi juga melahirkan efek-efek negatif, misalnya alienasi,

\footnotetext{
${ }^{34}$ Masykuri Abdillah dan Wahid Wahab, Demokrasi di persimpangan makna: respons intelektual muslim Indonesia terhadap konsep demokrasi (1966-1993) (PT Tiara Wacana, 1999).

35 Muhammad Fahmi, "Pendidikan Islam, Demokratisasi dan Kewarganegaraan," JOIES: Journal of Islamic Education Studies 1, no. 1 (2016): 87-110.
} 
ketidakpuasaan, ketidakstabilan atau perubahan yang terjadisecara terusmenerus ${ }^{36}$. Senada juga dengan konsep yang dibuat oleh Samuel P. Huntington bahwa kondisi globalisasi akan menyebabkan berbagai macam benturan khsusnya untuk peradaban.

Sebuah kenyataan yang harus diterima bersama, kekuatan globalisasi memang telah merasuk dalam sendi-sendi kehidupan bermasyarakat, dimanapun masyarakat itu berada, termasuk di Indonesia. Penggunaan teknologi "kotak" (handphone, televisi, internet, dan lain sebagainya) menjadikan dunia sangat sempit. Orang dalam hitungan detik dapat melakukan perubahan atau berubah mempengaruhi orang lain, karena pengaruh teknologi komunikasi yang begitu dahsyat.

Menurut Imam Barnadib dengan perkembangan informasi yang disebarkan melalui penyebaran informasi yang beraneka ragam, seolah-olah manusia "kebanjiran" berbagai informasi, seperti ilmu pengetahuan, iklan-iklan, baik barang maupun hiburan, maka tugas pendidikan adalah menyiapkan peserta didik bukan sekedar sebagai "penerima" informasi tetapi juga "penyeleksi" informasi melalui proses tabayun (instropeksi) ${ }^{37}$. Globalisasi dengan tema "modernitas" yang mengusung gaya hidup kapitalis dan liberalisasi ekonomimenggiring munculnya semangat kompetisi sehingga memposisikan kelompok masyarakat lain sebagai kompetitor bukan sebagai relasi atau mitra kerjasama dalam menghadapi kehidupan.

John Dewey juga dalam bukunya Democracy and Education menjelaskan bahwa tidak pada tempatnya untuk mengaitkan tatanan prilaku kelembagaan pendidikan dengan kebutuhan pasar kerja, mengingat pendidikan bertujuan meneruskan cita-cita demokrasi. Menurut John Dewey, agenda utama pendidikan secara fungsional adalah membentuk komunitas-komunitas sosial ideal sebagaibagian dari proses tranformasi pendewasaan peserta didik, apapun bentuk dan ragam pendidikan itu dikemas. Oleh karena itu lembaga pendidikan harus mampu untuk menyerap dan memfilter berbagai kebutuhan masyarakat sesuai dengan perkembangan zamanya.

Secara sistematis dalam menghadapi tantangan global dalam sistem pendidikan, peserta didik merupakan komponen input yang harus dikelola secara efektif dan efisien agar menjadi output yang berkualitas. Sebagai input pendidikan peserta didik sesungguhnya merupakan subyek yang harus mengikuti proses pembelajaran. Istilah siswa atau murid sering juga disebut peserta didik yang mana pada hakikatnya memerlukan bantuan orang dewasa untuk tumbuh dan berkembang sesuai dengan potensinya. Menurut Undang-undang sistem

36 Moch Miftachul Choiri dan Aries Fitriani, "Problematika pendidikan Islam sebagai sub sistem pendidikan nasional di era global," Al-Tahrir: journal of Islamic Thought 11, no. 2 (2011): 303-25.

${ }^{37}$ Imam Barnadib, "Filsafat Pendidikan: Sistem dan Metode," Yogyakarta, Andi Ofset, 1994. 
pendidikan nasional bahwa peserta didik adalah anggota masyarakat yang berusaha mengembangkan potensi diri. Melalui proses pembelajaran yang tersedia pada jalur, jenjang dan jenis pendidikan tertentu. Membahas tentang peserta didik pada dasarnya membahasa tentang hakikat manusia, karena sesungguhnya peserta didik adalah manusia, untuk itu kajian tentang peserta didik tidak lepas dari pembahasan tentang hakikat manusia ${ }^{38}$.

Untuk kepentingan jangka panjang pendidikan adalah investasi sumber daya manusia (SDM) jangka panjang yang mempunyai nilai strategis bagi kelangsungan peradaban manusia di dunia. Salah satu komponen penting dalam pendidikan adalah guru. Guru dalam konteks pendidikan mempunyai peranan yang besar dan strategis. Hal ini disebabkan karena guru yang berada di barisan terdepan dalam pelaksanaan pendidikan. Guru yang langsung berhadapan dengan peserta didik untuk mentransfer ilmu pengetahuan dan teknologi, sekaligus mendidik dengan nilai-nilai positif melalui bimbingan dan keteladanan. Guru adalah praktisi pendidikan yang sesungguhnya ${ }^{39}$. Selain itu guru adalah ruh dan model dalam pendidikan baik pada konsep pendidikan tradisional dan modern (global).

Mengingat strategisnya peran guru dalam pendidikan, apalagi di era global ini, maka kebutuhan akan guru yang profesional menjadi sebuah keniscayaan demi masa depan bangsa yang gemilang. Kebutuhan akan guru yang berkualitas yang semakin tinggi saat ini harus disikapi secara positif oleh LPTK (Lembaga Pengelola Tenaga Kependidikan). Tuntutan reformasi sistem pendidikan harus direspons positif dengan senantiasa meningkatkan mutu program pendidikan yang ditawarkannya.

Berdasarkan durasi waktu yang telah terjadi dan kita rasakan bersama bahwa Abad ke21 baru berjalan satu dekade, namun dalam dunia pendidikan sudah dirasakan adanya pergeseran, bahkan perubahan yang bersifat mendasar pada tataran filsafat, arah serta tujuannya. Tidaklah berlebihan bila dikatakan kemajuan ilmu tersebut dipicu oleh lahirnya sains dan teknologi komputer. Salah satu ciri yang paling menonjol pada abad ke-21 adalah semakin meningkatnya kebutuhan dalam dunia ilmu pengetahuan, sehingga sinergi di antaranya menjadi semakin cepat. Dalam konteks pemanfaatan teknologi informasi dan komunikasi di dunia pendidikan, telah terbukti semakin menyempitnya dan meleburnya faktor "ruang dan waktu" yang selama ini menjadi aspek penentu kecepatan dan keberhasilan penguasaan ilmu pengetahuan oleh umat manusia ${ }^{40}$.

\footnotetext{
38 Maarif, "Pendidikan Islam Dan Tantangan Modernitas (Input, Proses Dan Output Pendidikan Di Madrasah)."

39 Oviyanti, "Tantangan Pengembangan Pendidikan Keguruan di Era Global."

40 Badan Standar Nasional Pendidikan, "Paradigma pendidikan nasional abad XXI," Jakarta: BSNP, 2010.
} 
Berdasarkan fakta yang telah terjadi sekarang ini, iklim globalisasi telah melanda dunia pada umumnya dan bangsa Indonesia pada khususnya saat ini telah berada dalam gerbong globalisasi. Gerakan ini telah meberikan pengaruh ke seluruh lini kehidupan; dalam bidang ekonomi menjelma kapitalisme, dalam bidang politik menjelma menjadi demokratisasi dan penegakan hak asasi manusia, dalam aspek budaya berwujud kebebasan berekspresi, dalam interaksi sosial menjadi individualisme, dan lain sebagainya ${ }^{41}$. Beragam respon ditunjukkan masyarakat untuk menanggapi fenomena memudarnya sekat-sekat geografis yang membuat dunia menjelma menjadi sebuah kampung tanpa batas (borderless village) ini. Paling tidak, ada tiga paradigma pemikiran yang saling bersaing memperebutkan opini publik:

Pertama, paradigma yang menolak mentah-mentah globalisasi dengan asumsi bahwa fenomena ini adalah bentuk imperialisme gaya baru (neoimperialism). Ia tidak lain merupakan upaya Barat untuk kembali menanamkan kembali hegemoninya dan mengeksploitasi negaranegara lain. Hanya saja, untuk mengelabuhi publik, globalisasi sengaja disembunyikan di balik istilah-istilah atraktif dan slogan menarik, seperti keadilan, demokratisasi, hak asasi, kebebasan, perdamaian, good governance, dan lain-lain ${ }^{42}$.

Kedua, paradigma yang menerima secara mutlak karena meyakini bahwa globalisasi merupakan solusi paling ampuh dalam membawa kemakmuran bagi seluruh umat manusia. Kelompok ini juga mengklaimn bahwa globalisasi sejalan dengan prinsip universalisme Islam. Yusuf alQardhawi menolak dengan tegas klaim tersebut dengan mengadakan komparasi sebagai berikut: pertama, globalisasi berpijak pada prinsip "keberlangsungan bagi yang paling kuat" (albaqầ li al-aqwâ) sementara universalitas Islam berpijak pada prinsip kemuliaan manusia dan kesetaraan dalam memikul tugas dan tanggung jawab dalam memakmurkan bumi; kedua, dalam globalisasi interaksi antar pihak cenderung berbentuk pola hubungan antagonis atasan dan bawahan- sementara dalam konsep Islam bentuknya adalah persaudaraan dan partnership ${ }^{43}$.

Ketiga, paradigma moderat yang berpandangan tengah, yaitu bahwa globalisasi memang banyak mengandung sisi negatif, namun juga terdapat beberapa hal positif yang bisa diraih.

${ }^{41}$ Ali Miftakhu Rosyad, “al-Afkar, Journal for Islamic Studies URGENSI INOVASI PEMBELAJARAN DALAM PENDIDIKAN AGAMA ISLAM al-Afkar, Journal for Islamic Studies THE URGENCY OF LEARNING INNOVATION ON ISLAMIC RELIGIOUS STUDY” 3, no. 1 (2019), https://doi.org/10.5281/zenodo.2546882.

42 Aziza Meria, "Pendidikan Islam di era globalisasi dalam membangun karakter bangsa," Al-Ta'lim Journal 19, no. 1 (2012): 87-92.

${ }^{43}$ Meria. 
Satu hal yang jelas, fenomena ini tidak mungkin untuk ditolak atau dibendung maka tidak ada pilihan lain kecuali menghadapinya dengan hati-hati.

Dengan demikian, jika kita menalaah filsafat pendidikan yang dikembangkan oleh Paulo Freire yang menegaskan bahwa pendidikan harus difungsikan untuk pembebasan (liberation) dan bukan penguasaan (domination) maka pendidikan harus menjadi proses pemerdekaan. Sesuatu yang salah kaprah apabila pendidikan dijadikan instrumen untuk domestikasi dan bukan penjinakan sosial budaya (social and cultural domestication). Pendidikan bertujuan menggarap realitas manusia, sehingga secara metodologis bertumpu pada prinsip aksi dan refleksi total, yakni prinsip bertindak untuk mengubah realitas yang menindas sekaligus secara bersamaan dan terus menerus berusaha menumbuhkan kesadaran akan realitas dan hasrat untuk mengubah kenyataan yang menindas tersebut ${ }^{44}$.

Sampai saat ini role model yang dimiliki oleh seorang guru masih berada pada posisi yang relevan dalam perspektif pendidikan global. Untuk menghadapi sebuah tangangan pendidikan tersebut dibutuhkan sebuah guru yang profesional sesuai dengan kebutuhan zaman. Sedangkan arti profesional dalam dunia pendidikan adalah segenap kemampuan yang dimiliki oleh seorang guru untuk menjalankan tugasnya dengan penuh kesadaran dan tanggung jawab. Guru bukan saja dituntut melakukan tugasnya secara professional, tetapi juga harus memiliki pengetahuan dan kemampuan yang sesuai dengan bidang kompetensinya. Maka profesi seorang guru memiliki ciri-ciri khusus yaitu harus menguasai bidang ilmu pengetahuan yang akan diajarkannya dengan baik, harus memiliki kemampuan menyampaikan atau mengajarkan ilmu yang dimilikinya (transfer of knowledge) kepada muridmuridnya secara efektif dan efesien, dan berpegang teguh kepada kode etikprofessional ${ }^{45}$.

Ajaran Islam sebagai agama yang universal sangat kaya akan pesan-pesan yang mendidik bagi muslim menjadi umat terbaik, menjadi khalifah yang mengatur bumi beserta isinya. Dalam perspektif pendidikan Islam yang dimaksud dengan profesional adalah kemampuan seseorang dalam menjalankan amanah, tugas, dan kewajibanya sebagai kholifah fil ardi untuk mencapai keridhoal Allah Swt.

Berdasarkan beberapa uraian diatas maka dapat diambil kesipulan bahwa tantangan global dalam dunia pendidikan akan datang secara berkelanjutan dan kita tidak akan bisa menghindari tantangan tersebut. Hal yang positif yang perlu dikembangkan oleh lembaga

44 Andik Wahyun Muqoyyidin, "Membangun kesadaran inklusifmultikultural untuk deradikalisasi pendidikan Islam," Jurnal Pendidikan Islam 2, no. 1 (2013): 131-51.

45 Anggun Wulan Fajriana dan Mauli Anjaninur Aliyah, "Tantangan Guru dalam Meningkatan Mutu Pendidikan Agama Islam Di Era Melenial,” Naz̧hruna: Jurnal Pendidikan Islam 2, no. 2 (2019): 246-65. 
Pradigma Pendidikan Demokrasi,...

pendidikan dalam menghadapi tantangan tersebut adalah mempersiapkan Sumber Daya Manusia sebaik mungkin agar mereka bisa dan siap untuk bersaing.

\section{Inovasi Sistem Pendidikan dalam menghadapi Tantangan Global}

Secara umum letak permasalahan pendidikan di Indonesia berada pada kualitas, relevansi, elitisme, dan manajemen. Berbagai indikator kuantitatif dikemukakan berkenaan dengan keempat masalah di atas, antara lain analisis komparatif yang membandingkan situasi pendidikan antara negara di kawasan Asia. Keempat masalah tersebut merupakan masalah besar, mendasar, dan multidimensional, sehingga sulit dicari ujung pangkal pemecahannya. Permasalahan ini terjadi pada pendidikan secara umum di Indonesia, termasuk pendidikan Islam yang dinilai justru mengalami problematika yang demikian ${ }^{46}$.

Sampai saat ini apabila kita perhatikan situasi dan kondisi pendidikan Islam terkukung dalam kemunduran, keterbelakangan, ketidak berdayaan, dan kemiskinan, sebagaimana pula yang dialami oleh sebagian besar negara dan masyarakat Islam dibandingkan dengan mereka yang non Islam. Pendidikan Islam menempati posisi urgen dalam sistem pendidikan nasional, tetapi predikat keterbelakangan dan kemunduran tetap melekat padanya, bahkan pendidikan Islam sering "dinobatkan" hanya untuk kepentingan orang-orang yang tidak mampu atau miskin, memproduk orang yang eksklusif, dan fanatik.

Ada anggapan dewasa ini yang sangat menyedihkan bagi kita umat islam yang itu dengan adanya kosakata "terorisme-pun" dianggap berasal dari lembaga pendidikan Islam, karena pada kenyataannya beberapa lembaga pendidikan Islam "dianggap" sebagai tempat berasalnya kelompok tersebut. Walaupun “anggapan” ini keliru dan dapat ditolak, sebab tidak ada lembaga-lembaga pendidikan Islam manapun yang bertujuan untuk memproduk atau mencetak kelompok-kelompok orang seperti itu. Tetapi realitas di masyakarat banyak perilaku kekerasan yang mengatasnamakan Islam. Apakah ada sesuatu yang salah dalam sistem, proses, dan orientasi pendidikan Islam $^{47}$.

Berdasarkan catatan sejarah membuktikan bahwa pendidikan adalah istrumen esensial yang akan menopang kemajuan suatu bangsa. Kemajuan suatu bangsa dapat diukur dari kualitas dan sistem pendidikan yang ada. Suatu negara dianggap jauh dan tertinggal dari negara lain, manakala kualitas pendidikannya rendah. Kualitas pendidikan di Indonesia pada dewasa ini sangat memprihatinkan. Ini terbukti di antaranya dengan data UNESCO (2000) tentang

46 Henry Alexis Rudolf Tilaar, Sistem pendidikan nasional yang kondusif bagi pembangunan masyarakat industri modern berdasarkan Pancasila (Sekretariat Pusat Analisa Perkembangan Iptek-LIPI, 1991).

${ }^{47}$ Hujair A H Sanaky, "Permasalahan dan Penataan Pendidikan Islam Menuju Pendidikan yang Bermutu," El-Tarbawi 1, no. 1 (2008). 
peringkat Indeks Pengembangan Manusia (Human Development Index), yaitu komposisi dari peringkat pencapaian pendidikan, kesehatan, dan penghasilan perkepala yang menunjukkan bahwa indeks pengembangan manusia Indonesia makin menurun ${ }^{48}$.

Supaya kita bisa keluar dari ketertinggalan dan memutuskan mata rantai keterbelakangan dalam Sumber Daya Manusia perlu adanya inovasi pendidikan secara menyeluruh. Secara sistematis arah tujuan inovasi pendidikan Indonesia, adalah: (1) Mengejar berbagai ketinggalan dari berbagai kemajuan ilmu pengetahuan dan teknologi, sehingga pada akhirnya pendidikan di Indonesia semakin berjalan sejajar dengan berbagai kemajuan tersebut. (2) Mengusahakan terselenggarakannya pendidikan di setiap jenis, jalur, dan jenjang yang dapat melayani setiap warga Negara secara merata dan adil. (3) Mereformasi sistem pendidikan Indonesia yang lebih: efisien dan efektif, menghargai kebudayaan nasional, lancar dan sempurnanya sistem informasi kebijakan, mengokohkan identitas dan kesadaran nasional, menumbuhkan masyarakat gemar belajar, menarik minat peserta didik, dan banyak menghasilkan lulusan yang benar-benar diperlukan untuk berbagai bidang pekerjaan yang ada di kehidupan masyarakat ${ }^{49}$.

Secara mendasar inovasi pendidikan perlu dilakukan mulai dari inovasi kurikulum terlebih dahulu. Karena kurikulum pendidikan adalah sub sistem pendidikan yang secara praktis menentukan bagaimana seharusnya pembelajaran dilakukan sebagaimana dikatakan oleh Prastyawan adalah ${ }^{50}$ sebagai berikut:

a. Perkembangan ilmu pengetahuan menghasilkan kemajuan teknologi yang mempengaruhi kehidupan sosial, ekonomi, politik, pendidikan, dan kebudayaan bangsa Indonesia.

b. Laju eksplosi penduduk yang cukup pesat, yang menyebabkan daya tampung, ruang, dan fasilitas pendidikan yang sangat tidak seimbang.

c. Melonjaknya aspirasi masyarakat untuk memperoleh pendidikan yang lebih baik, sedangkan dipihak lain kesempatan sangat terbatas.

d. Mutu pendidikan yang dirasakan makin menurun, yang belum mampu mengikuti perkembangan ilmu pengetahuan dan teknologi.

48 Titi Kadi dan Robiatul Awwaliyah, "Inovasi Pendidikan: Upaya Penyelesaian Problematika Pendidikan Di Indonesia," Jurnal Islam Nusantara 1, no. 2 (2017).

49 Kusnandi Kusnandi, "MODEL INOVASI PENDIDIKAN DENGAN STRATEGI IMPLEMENTASI KONSEP 'DARE TO BE DIFFERENT,”' Jurnal W ahana Pendidikan 4, no. 1 (2019): 132-44.

50 P Prastyawan, "Inovasi Kurikulum dan Pembelajaran," Al Hikmab: Jurnal Studi Keislaman 1, no. 2 (2011): 5. 
e. Belum berkembangnya alat organisasi yang efektif, serta belum tumbuhnya suasana yang subur dalam masyarakat untuk mengadakan perubahan perubahan yang dituntut oleh keadaan sekarang dan yang akan datang.

f. Kurang ada relevansi antara program pendidikan dan kebutuhan masyarakat yang sedang membangun.

g. Keterbatasan dana.

Reformasi pendidikan dalam bidang perkembangan teknologi informasi yang sedemikian cepat tidak saja mengubah cara orang berkomunikasi dan bekerja, namun lebih jauh lagi telah membuat iklim persaingan baru. Five Forces (lima kekuatan) yang harus dicermati oleh berbagai pihak pimpinan lembaga pendidikan. Five Forces dapat dijelaskan sebagai berikut: (1) Persaingan antar lembaga pendidikan yang sudah ada (rivalry among existing institution). (2) Ancaman dari lembaga pendidikan pendatang baru (threat of new entrant). (3) Ancaman dari suatu lembaga pendidikan yang mana menawarkan jasa pendidikan pengganti (threat of substitute educations service). (4) Kekuatan tawar-menawar pemasok/masyarakat yang membutuhkan jasa pendidikan (bargainning power of suppliers). (5) Kekuatan tawar-menawar pembeli (bargaining power of buyer) ${ }^{51}$.

Untuk mendukung suatu inovasi pendidikan yang paling mendasar perlu adanya inovasi terhadap Kualitas dan kompetensi guru dianggap memiliki pengaruh terbesar terhadap kualitas pendidikan. Oleh sebab itu, sudah sewajarnya apabila guru dituntut untuk bertindak secara profesional dalam melaksanakan proses belajar mengajar guna meningkatkan kualitas pendidikan yang mereka lakukan. Tuntutan seperti ini sejalan dengan perkembangan masyarakat modern yang menghendaki bermacam-macam spesialisasi yang sangat diperlukan dalam masyarakat yang semakin lama semakin kompleks. Tuntutan kerja secara profesional juga dimaksudkan agar guru berbuat dan bekerja sesuai dengan profesi yang disandangnya ${ }^{52}$.

Berdasarkan berbagai konsep yang dikemukakan tersebut, paradigma pendidikan demokrasi dan pendidikan islam sangat merekomendasikan adanya inovasi pendidikan untuk menjawab tantangan globalisasi yang terjadi. Tanpa adanya inovasi pendidikan akan menjadi kolot, ketinggalan zaman, dan kehilangan relevansinya. Namun untuk mewujudkan sebuah

51 Hasan Baharun, "Pengembangan Media Pembelajaran PAI Berbasis Lingkungan Melalui Model ASSURE," Cendekia: Jurnal Kependidikan Dan Kemasyarakatan 14, no. 2 (2016): 231-46.

52 Kadi dan Awwaliyah, "Inovasi Pendidikan: Upaya Penyelesaian Problematika Pendidikan Di Indonesia." 
inovasi perlu adanya dukungan bersama dari para praktisi pendidikan, pemegang kekuasaan pendidikan, dan masyarakat.

\section{KESIMPULAN}

Berdasarkan pembahasan tersebut dapat ditarik kesimpulanya adalah, Pertama, paradigma pendidikan demokrasi merekomendasikan sistem penyelenggaraan pendidikan dengan melibatkan partisipasi sosial yang meliputi pendidik, tenaga kependidikan, pemerintah, dan masyarakat secara bersama-sama untuk memperbaiki sistem pendidikan nasional. Selain itu demokratisasi pendidikan adalah pengembangan berkelanjutan dari reformasi pendidikan yang sudah lama digulirkan di Indonesia, Kedua, pendidikan Islam merupakan proses sosialisasi dan internalisasi nilai-nilai ajaran Islam yang bersumber pada Alquran dan Hadis untuk diaktualisasikan melalui proses pembelajaran. Pelaksanaan pendidikan Islam akan mencapai hasil yang maksimal apabila dilakukan dengan mempertimbangkan materi, metode, dan media yang tepat, dan Ketiga, tantangan global dalam pendidikan sudah menjadi sunnatullah yang tidak mungkin bisa dihindari, dengan demikian peran lembaga pendidikan adalah mempersiapkan Sumber Daya Manusia yang handa untuk dapat bersaing secara profesional. Keempat, inovasi pendidikan perlu dilaksanakan secara serius dan berkelanjutan untuk menjawab berbagai tantangan globalisasi. Inovasi sistem pendidikan akan melibatkan berbagai praktisi pendidikan, pemerintah, dan masyaraka sekitar secara bersamaan.

\section{REFERENSI}

Abdillah, Masykuri, dan Wahid Wahab. Demokrasi di persimpangan makna: respons intelektual muslim Indonesia terbadap konsep demokrasi (1966-1993). PT Tiara Wacana, 1999.

Abdullah, Muhammad Amin. "Islamic Studies in Higher Education in Indonesia: Challenges, Impact and Prospects for the World Community." Al-Jami'ab: Journal of Islamic Studies 55, no. 2 (15 Desember 2017): 391-426. https://doi.org/10.14421/ajis.2017.552.391426.

Aharish, Mohammad Hamid Mohammad al-. "Indonesian Islam and Social Challenges Between Moral Cultivation and Intellectual Movement." Journal of Indonesian Islam 11, no. 2 (6 Desember 2017): 551-568-568. https://doi.org/10.15642/JIIS.2017.11.2.551568. 
Pradigma Pendidikan Demokrasi,...

Ainiyah, Nur. "Pembentukan Karakter Melalui Pendidikan Agama Islam." Al-Ulum 13, no. 1 (2013): 25-38.

Aprilianto, Andika, dan Muhammad Arif. "Pendidikan Islam Dan Tantangan Multikultural: Tinjauan Filosofis.” Ną̧hruna: Jurnal Pendidikan Islam 2, no. 2 (11 Agustus 2019): 279_ 89. https://doi.org/10.31538/nzh.v2i2.339.

Arif, Mahmud. "Pendidikan Agama Islam Inklusifmultikultural." Jurnal Pendidikan Islam 1, no. 1 (2011): 1-18.

Arifin, Akhmad Hidayatullah Al. "Implementasi Pendidikan Multikulutral dalam Praksis Pendidikan di Indonesia." Jurnal Pembangunan Pendidikan: Fondasi dan Aplikasi 1, no. 1 (2012).

Asrori, Achmad. "Contemporary Religious Education Model on the Challenge of Indonesian Multiculturalism." JOURNAL OF INDONESLAN ISLAM 10, no. 2 (1 Desember 2016): 261-84. https://doi.org/10.15642/JIIS.2016.10.2.261-284.

Baharun, Hasan. "Pengembangan Media Pembelajaran PAI Berbasis Lingkungan Melalui Model ASSURE." Cendekia: Jurnal Kependidikan Dan Kemasyarakatan 14, no. 2 (2016): 231-46.

Barnadib, Imam. "Filsafat Pendidikan: Sistem dan Metode.” Yogyakarta, Andi Ofset, 1994.

Bhaskar, Roy. “The Possibility of Naturalism,(2nd edn) Hemel Hempstead: Harvester Wheatsheaf," 1989.

Choiri, Moch Miftachul, dan Aries Fitriani. "Problematika pendidikan Islam sebagai sub sistem pendidikan nasional di era global." Al-Tabrir: journal of Islamic Thought 11, no. 2 (2011): 303-25.

Dali, Zulkarnain. "Pendidikan Islam Multikultural.” Nuansa 10, no. 1 (2017).

Driyarkara, Nicolaus. Driyarkara tentang pendidikan. Vol. 1. Yayasan Kanisius, 1980.

Fahmi, Muhammad. "Pendidikan Islam, Demokratisasi dan Kewarganegaraan.” JOIES: Journal of Islamic Education Studies 1, no. 1 (2016): 87-110.

Fajriana, Anggun Wulan, dan Mauli Anjaninur Aliyah. "Tantangan Guru dalam Meningkatan Mutu Pendidikan Agama Islam Di Era Melenial.” Ną̧runa: Jurnal Pendidikan Islam 2, no. 2 (2019): 246-65.

Ibrahim, Rustam. "Pendidikan Multikultural: Pengertian, Prinsip, dan Relevansinya dengan Tujuan Pendidikan Islam.” Addin 7, no. 1 (2015).

Indonesia, Republik. "Undang-undang Republik Indonesia nomor 20 tahun 2003 tentang sistem pendidikan nasional." Jakarta: Pemerintah Republik Indonesia, 2003. 
Irham, Irham, dan Yudril Basith. "Revitalisasi Makna Guru Dari Ajaran Tasawuf Dalam Kerangka Pembentukan Karakter." Ulul Albab Jurnal Studi Islam 19, no. 1 (25 Juni 2018): 44-68. https://doi.org/10.18860/ua.v19i1.4901.

Izfanna, Duna, dan Nik Ahmad Hisyam. "A comprehensive approach in developing akhlaq: A case study on the implementation of character education at Pondok Pesantren Darunnajah.” Multicultural Education \& Technology Journal 6, no. 2 (8 Juni 2012): 77-86. https://doi.org/10.1108/17504971211236254.

Kadi, Titi, dan Robiatul Awwaliyah. "Inovasi Pendidikan: Upaya Penyelesaian Problematika Pendidikan Di Indonesia." Jurnal Islam Nusantara 1, no. 2 (2017).

Kosim, Muhammad, Martin Kustati, Ahmad Sabri, dan Mujahidil Mustaqim. "Strengthening Students' Character through Tahfidz Quran in Islamic Education Curriculum.” Jurnal Pendidikan Islam 8, no. 1 (4 September 2019): 69-94. https://doi.org/10.14421/jpi.2019.81.69-94.

Kunci, Kata. "The Urgency of Holistic and Comprehensive Character Education in Indonesia." Jurnal Pendidikan Karakter, 2013, 8.

Kusnandi, Kusnandi. "MODEL INOVASI PENDIDIKAN DENGAN STRATEGI IMPLEMENTASI KONSEP 'DARE TO BE DIFFERENT."' Jurnal Wahana Pendidikan 4, no. 1 (2019): 132-44.

Leavy, Brian. "Effective leadership today - character not just competence." Strategy \& Leadership 44, no. 1 (11 Januari 2016): 20-29. https://doi.org/10.1108/SL-11-20150081.

Maarif, Muhammad Anas. "Internalisasi Nilai Multikulutural Dalam Mengembangkan Sikap Toleransi (Studi Di Di Pesantren Mahasiswa Universitas Islam Malang).” Ną̧hruna: Jurnal Pendidikan Islam 2, no. 1 (2019): 164-89.

—. "Optimalisasi Pembelajaran Pendidikan Islam Di Sekolah/Madrasah Upaya Dan Faktor Penghambat Pembelajaran Pendidikan Islam." FALASIFA: Jurnal Studi Keislaman 8, no. 2 (2017): 273-90.

- "Pendidikan Islam Dan Tantangan Modernitas (Input, Proses Dan Output Pendidikan Di Madrasah)." Nidhomul Haq: Jurnal Manajemen Pendidikan Islam 1, no. 2 (2016): 47-58.

Meria, Aziza. "Pendidikan Islam di era globalisasi dalam membangun karakter bangsa." AlTa'lim Journal 19, no. 1 (2012): 87-92. 
Pradigma Pendidikan Demokrasi,...

Muliadi, Erlan. "Urgensi Pembelajaran Pendidikan Agama Islam Berbasis Multikultural di Sekolah.” Jurnal Pendidikan Islam 1, no. 1 (2011): 55-68.

Muqoyyidin, Andik Wahyun. "Membangun kesadaran inklusifmultikultural untuk deradikalisasi pendidikan Islam.” Jurnal Pendidikan Islam 2, no. 1 (2013): 131-51.

Musfah, Jejen, dan Desita Erviani. "School of Master Teacher (Smt) Training: Developing Teachers' Pedagogic Competence." TARBIYA: Journal of Education in Muslim Society 5, no. 2 (2018): 126-34. https://doi.org/10.15408/tjems.v5i2.10622.

Muslih, Mohammad. FILSAFAT ILMU; Kajian atas Asumsi Dasar, Paradigma, dan Kerangka Teori Ilmu Pengetabuan. LESFI, 2016.

Nasucha, Juli Amaliya. "Pendidikan Islam Dan Tantangan Globalisasi." JOIES: Journal of Islamic Education Studies 1, no. 1 (7 September 2016): 205-18.

Oviyanti, Fitri. "Tantangan Pengembangan Pendidikan Keguruan di Era Global." Nadwa 7, no. 2 (2016): 267-82.

PAI, A Pengertian Pendidikan Agama Islam. "Pendidikan Agama Islam," 1998.

Pendidikan, Badan Standar Nasional. "Kurikulum Tingkat Satuan Pendidikan." Jakarta: Departemen Pendidikan Nasional, 2006.

—. "Paradigma pendidikan nasional abad XXI." Jakarta: BSNP, 2010.

Prastyawan, P. "Inovasi Kurikulum dan Pembelajaran." Al Hikmah: Jurnal Studi Keislaman 1, no. 2 (2011): 5 .

Priyatna, Tedi. "Inovasi pembelajaran PAI di sekolah pada era disruptive innovation." Jurnal Tatsqif 16, no. 1 (2018): 40.

Rohmat, Rohmat, Zamroni Zamroni, dan Achmad Dardiri. "Perspektif Multikultural pada Pendidikan Agama Islam di Madrasah Aliyah.” Jurnal Pembangunan Pendidikan: Fondasi dan Aplikasi 3, no. 1 (2015): 31-43.

Rosyad, Ali Miftakhu. "al-Afkar, Journal for Islamic Studies URGENSI INOVASI PEMBELAJARAN DALAM PENDIDIKAN AGAMA ISLAM al-Afkar, Journal for Islamic Studies THE URGENCY OF LEARNING INNOVATION ON ISLAMIC RELIGIOUS STUDY” 3, no. 1 (2019). https://doi.org/10.5281/zenodo.2546882.

- "The IMPLEMENTASI NILAI-NILAI MULTIKULTURALISME MELALUI PEMBELAJARAN PENDIDIKAN AGAMA ISLAM (THE IMPLEMENTATION OF MULTICULTURALISM VALUES THROUGH LEARNING OF ISLAMIC RELIGION EDUCATION).” Risâlah, Jurnal Pendidikan dan Studi Islam 5, no. 1 (2019): $1-18$. 
Rosyada, Dede. Paradigma pendidikan demokratis: sebuah model pelibatan masyarakat dalam penyelenggaraan pendidikan. Prenada Media, 2004.

Sanaky, Hujair A H. "Permasalahan dan Penataan Pendidikan Islam Menuju Pendidikan yang Bermutu." El-Tarbawi 1, no. 1 (2008).

Subandi, Subandi, Ahmad Fauzan, Muhammad Muchsin Afriyadi, dan Mispani Ramli. "Implementation of Multicultural and Moderate Islamic Education at the Elementary Schools in Shaping the Nationalism." Tadris: Jurnal Keguruan Dan Ilmu Tarbiyab 4, no. 2 (27 Desember 2019): 247-55. https://doi.org/10.24042/tadris.v4i2.5003.

Suharto, Toto. "Indonesianisasi Islam: Penguatan Islam Moderat dalam Lembaga Pendidikan Islam di Indonesia." Al-Tabrir: Jurnal Pemikiran Islam 17, no. 1 (2017): 155-78.

—. "Konsep dasar pendidikan berbasis masyarakat." Jurnal Cakrawala Pendidikan, no. 3 (2005).

Suparta, Mundzier. "Pendidikan Transformatif Menuju Masyarakat Demokratis." ISLAMICA: Jurnal Studi Keislaman 7, no. 2 (23 Januari 2014): 406-25. https://doi.org/10.15642/islamica.2013.7.2.406-425.

Suryadi, Rudi Ahmad. "Visi dan Paradigma Pendidikan Agama Islam (PAI): Kualitas, Integratif, dan Kompetitif." EDUKASI: Jurnal Pendidikan Islam 4, no. 2 (2016): 253-76.

Thohir, Mudjahirin. "Nasionalisme Indonesia: Membingkai Pluralitas dalam Kedamaian." dalam Zudi Setiawan, Nasionalisme NU, Semarang: Aneka Ilmu, 2007.

Tilaar, Henry Alexis Rudolf. Sistem pendidikan nasional yang kondusif bagi pembangunan masyarakat industri modern berdasarkan Pancasila. Sekretariat Pusat Analisa Perkembangan IptekLIPI, 1991.

Yusnita, Yeni, Fitri Eriyanti, Engkizar Engkizar, Fuady Anwar, Nofrina Eka Putri, Zainul Arifin, dan Syafrimen Syafril. "The Effect of Professional Education and Training for Teachers (PLPG) in Improving Pedagogic Competence and Teacher Performance.” Tadris: Jurnal Keguruan dan Ilmu Tarbiyah 3, no. 2 (28 Desember 2018): 123-30. https://doi.org/10.24042/tadris.v3i2.2701.

Zainuddin, Ammar, dan Juli Amaliya Nasucha. "The Internalization of Sunan Drajat Social Concept in Multicultural Education Implementation." Al-Tadrkiyyah: Jumal Pendidikan Islam 9, no. 1 (30 Mei 2018): 167-80. https://doi.org/10.24042/atjpi.v9i1.2958.

Zamroni. Pendidikan untuk demokrasi: tantangan menuju civil society. Bigraf Pub., 2001. 